The 1st International Symposium on Aquatic Product Processing 2013

\title{
GROWTH PERFORMANCE AND HISTOLOGICAL APPEARANCE OF THE HUMPBACK GROUPER JUVENILE (CROMILEPTESALTIVELIS) AFTER TREATED WITH RECOMBINANT GROWTH HORMONE
}

\author{
Suci Antoro1)*, M. Zairin Junior2), Alimuddin2)*, Agus Suprayudi2), Irvan Faizal3) \\ 1) Main Center for Mariculture Development, Ministry of the Marine and Fishery Indonesia \\ 2)Aquaculture Department, Bogor Agriculture University, Indonesia \\ 3)Agency for Assessment and Applicationof Technology (BPPPT), Indonesia \\ *e-mail: suciantoro@yahoo.com; alimuddin_alsani@yahoo.com
}

\begin{abstract}
Despite as high price consumption fish, humpback grouper grow out take very long time so its culture considered not efficient. Therefore to accelerate its growth rate and make grow out culture more efficient, recombinant Epinepheluslanceolatus growth hormone (rEIGH) was applied by oral route. Daily application of rough rEIGH at a dose of $5 \mathrm{mg} / 100 \mathrm{~g}$ commercial diet for 42 days resulted significance increase in growth rate compared to control groups. No specific histological damage on kidney, liver and spleen which was attributable to $r E I G H$ administration. These results strongly suggested that growth stimulation following oral administration was due to a specific action of $\mathrm{rEIGH}$ and recombinant $\mathrm{GH}$ as mentioned above save for fish consumption.
\end{abstract}

Key words: growth, histology, humpback grouper, recombinant growth hormone

\section{INTRODUCTION}

Growth hormone (GH)is one of polypeptide hormone contain nearly 200 amino acids, produced and secreted by somatotroph cells of vertebrate anterior pituitary gland. This hormone has two major actions: (1) direct metabolic effects that facilitatemuscle growth and glucose sparing and (2) skeletal growth effects that arepartially direct and partially mediated by IGF-I (Bolander 2004). More recently several authors stated that GH participated in nearly all main physiologic processes such as ionic and osmotic regulation; protein, lipid and carbohydrate metabolisms as well as reproduction and immune (Reinecke et al., 2005; Birzniece et al., 2009; Hattori, 2009).

Within the last 3 decades, the growth promoting effects of $\mathrm{GH}$ have been well documented in a variety of species of fish either as endogenous or exogenous hormone(Donaldson et al., 1979; Moriyama and Kawauchi, 2001). Studies investigating the use of recombinant growth hormone $(\mathrm{rGH})$ for promoting growth in salmonids (Sekine et al., 1985; Moriyama, 1995), rainbow trout (Moriyama et al., 1993), red seabream (Bin et al.,2001), flounder (Liu et al.,2008), tilapia (Li et al., 2003; Acosta et al., 2007), rabbitfish (Funkenstein et al., 2005), goldfish (Promdonkoy et al., 2004), black seabream (Tsai et al., 1997), Indonesian eel (Handoyo, 2012), giant gourami (Irmawati, 2013) and many others species found that rGHable to accelerate thegrowth. Donaldson et al. (1979) suggested that exogenous $\mathrm{GH}$ enhances fish growth by stimulating appetiteand then improving feed and protein conversion; while Silverstein et al. (1999) suggested GH might stimulate food intake 
indirectly through metabolic changes such as increased utilization of nutrients that feedback on hypothalamic centers regulating energy balance.

Regarding to the potential food safety and environmental safety issues associated with transgenic fish (Muir and Howard, 1999), the use of transgenic organism to produce rGHfor increasing yields in aquaculture has generated considerable interest (Leedom et al., 2002). One method that could be used to verify the safety of exogenous substances in target organism is histopathological examination as were done byFarris et al. (2007), Liu et al. (2008) and Irmawati (2013).

While the advantage of $\mathrm{rGH}$ was studied elsewhere for various species, no one study was done to humpback grouper. This species is one of major marine fish consumption culturing in Indonesia, and has high price but very low growth rate. In the present study, for the first time we studied the effect of $\mathrm{rGH}$ on growth, survival, feed efficiency, muscle composition and histology of liver, spleen and kidney of the humpback grouper juvenile. Liver, spleen and kidney are vital organs for vertebrate, subsequently serve as major role in metabolism, natural filter of the blood and remove wastes, and immune system. The objectivesof this study were to verify the effectiveness and the safety of rGHas feed additive to promote growth of the species studied.

\section{MATERIALS AND METHODS}

\section{Production of protein $\mathrm{FEIGH}$ and preparation of feed}

Escherichia colistrain BL21 harboring pCold-EIGHprotein expression vectorwas used as bioreactor for producing rEIGH.Bacteria culture, extractionand verification of protein $r E I G H$ were done according to Alimuddin et al. (2010).To protect rEIGH from proteolitic digestive enzyme, the protein was coated by hydroxypropylmethyl cellulose phthalate (HP55, Shinetsu, Japan) as described by Moriyama et al.(1993) before it mixed with commercial diet (CD).

\section{Experimental design}

The experiment was conducted for 42 days with five treatment groups; (1) C- or control negative (fed with $C D$ ), (2) $C+$ or control positive (CD with placebo), (3) pA(CD with $0.2 \mathrm{mg}$ rEIGH-HP55/100 g feed), (4) pB (CDwith $1 \mathrm{mg} \mathrm{rEIGH-HP55/100} \mathrm{gfeed)} \mathrm{and} \mathrm{(5)} \mathrm{pC} \mathrm{(CD} \mathrm{with}$ $5 \mathrm{mg}$ rEIGH-HP55/100 $\mathrm{g}$ feed).The serial doses was found from preliminary test.CD was bought from Japanese Company contains approximately $48.70 \%$ crude protein and $13.30 \%$ crude lipid.

\section{Fish husbandry and experimental protocol}

Humpback grouper juveniles (body weight $1.44 \pm 0.30$ g)obtained from Main Center for Mariculture Development, Lampung, Directorate General of Aquaculture, Ministry of Marine and Fishery, were randomly distributed into 15 buckets $(45 \times 45 \times 45 \mathrm{~cm}), 50$ fish per bucket,3buckets per treatment group. Each bucket in the same treatment group was fitted in 2000-Lfiber glass tank respectively.They were fed with CD and acclimatized to the 
experimentalconditions for 1 week. Fishes were reared under natural photoperiod and suppliedwith sand-filtrated seawater continuously. The watertemperature (28-29.0 $\left.{ }^{\circ} \mathrm{C}\right)$, salinity $(31-32 \% 0), \mathrm{pH}(8.0-8.5)$ and dissolved oxygen level $(5-6 \mathrm{mg} / \mathrm{l})$ of the water weremonitored routinely and maintained within the limits. Uneaten feed, feces and other dirties were siphoned daily. Fish were hand fed three times a day (at 08:30; 12:30 and 16.30) toapparent satiation. The amount of feed consumed (FC) in each bucketaccording to the treatment groups and the number as well as weight of fish died were recorded daily. Total body weight of fish were measured once time per 2 weeks.

\section{Chemical analysis of body muscle}

At the end of the 42 days trial, body muscles of 3 fish in each aquarium weredissected and pooled together for proximate analysis of muscle. Specimens ofmuscle were homogenized, $5 \mathrm{~g}$ aliquot was oven-dried to constant weight at $105{ }^{\circ} \mathrm{C}$ to estimate the moisture content, while the remaining samples werelyophilized and stored at $-20{ }^{\circ} \mathrm{C}$ for chemical analysis. Kjeldahl and $\mathrm{HCl}$ hydrolysis methods were employed to determine the protein and lipid content,respectively. Protein, lipidand moisture content in each sample were determined in triplicate.

The content of muscle and liver glycogen were determined by multiplication of absorbent sample with $\mathrm{mg} / \mathrm{ml}$ dilution then divide by absorbentstandard. Absorbent sample was obtained from a serial process which was involved heating, centrifugation, hydrolysis and measuring absorbent value by spectrophotometer. Spectrophotometer was also used for measure plasma glucose.

\section{Histological study}

At the end of feeding trial, samples of liver, spleen andkidney were taken from 3 fish from control groups and best dose respectively, for histopathological evaluation. Liver of all fishin each group was weighed for the determination of hepatosomatic index.All samples were fixed in fixative buffered formalin, dehydrated in agraded ethanol series, embedded in paraffin and sectioned to $4 \mu \mathrm{m}$ with a rotarymicrotome. Sections were stained with haematoxylin and eosin (H\&E) andobserved under light microscope.

\section{Calculations and statistical analysis}

Specific growth rate $(S G R)$ was calculated as $(\ln W 2-\ln W 1) \times 100 /$ time, survival (SR) was $\mathrm{Nt} / \mathrm{NO} \times 100$, feed efficiency (FE)was calculated as (W2+WD)-W1/feed consumed $x 100, \Delta W$ was difference between $W 2$ and $W 1$, protein retention (PR) was calculated as $\mathrm{Pbt}-\mathrm{PbO} / \mathrm{Pc} \times 100$ and lipid retention (LR) was calculated as $\mathrm{Lbt}-\mathrm{LbO} / \mathrm{Lc} \times$ 100. W2, W1,WD, Nt, NO,Pbt, PbO,Lbt and LbO are represent final body weight, initial body weight, died body weight, final number, initial number, final protein body, initial protein body, final lipid body and initial lipid body of fish, respectively; while Pc and Lcsuccessively represent as protein consumed and lipid consumed. Hepatosomatic index (HSI) was calculated as liver weight $\times 100 /$ body weight. All data between treatment groups were analyzed by 
one-way ANOVA, followed by Duncan's Multiple Range Test of Significance. Difference was regarded as significant when $\mathrm{P}<0.05$.

\section{RESULTS AND DISCUSSION}

Fish growth performance was presented in Table 1.Although during the 42 days trial there were some fish died in $C+, p B$ and $p C$ but the survival rate (SR) differences among experimental groupswere not significant. Final body weight (W2), SGR, FC and FE of the rGHtreatment groups were significantly different than two control groups; however the difference between two control groups were not significant. These results indicated that the growth-promoting effect was caused by $r E I G H$, not by the placebo itself. $\triangle$ Wof $p A, p B$ and pCsubsequently were $23.69 \%, 31.45 \%$ and $40.25 \%$ higher than $\Delta$ Wof C-. The figure of pCwas highest than other experimental groups, it isindicated that the dose for $\mathrm{pCwas}$ better than $\mathrm{pB}$ and $\mathrm{pA}$.

Table 1. Effect of rEIGH on survival, growth, feed consumed and feed efficiency of humpback grouper juvenile.

\begin{tabular}{|c|c|c|c|c|c|c|c|}
\hline $\begin{array}{c}\text { Grou } \\
p\end{array}$ & SR (\%) & W2 (g) & $\Delta W(g)$ & $\begin{array}{c}\% \Delta \mathrm{W} \\
\text { to } \\
\text { Control } \\
-\end{array}$ & SGR & $\mathrm{FC}(\mathrm{g})$ & FE (\%) \\
\hline $\mathrm{C}-$ & $100^{a}$ & $\begin{array}{l}5,92 \pm 1,1 \\
7 \mathrm{a}\end{array}$ & $\begin{array}{l}4,77 \pm 0,2 \\
9 \text { a }\end{array}$ & & $\begin{array}{l}3,92 \pm 0, \\
12 \text { a }\end{array}$ & $\begin{array}{l}217.12 \pm 3 . \\
45^{\mathrm{a}}\end{array}$ & $\begin{array}{l}109,81 \pm 5 \\
, 60 \text { a }\end{array}$ \\
\hline$C+$ & $\begin{array}{l}99,33 \pm 1 \\
15 \text { a }\end{array}$ & $\begin{array}{l}6,23 \pm 1,0 \\
9 \text { a }\end{array}$ & $\begin{array}{l}5,08 \pm 0,2 \\
5 \text { a }\end{array}$ & 6,5 & $\begin{array}{l}4,04 \pm 0 \\
10 \text { a }\end{array}$ & $\begin{array}{l}226.04 \pm 7 . \\
30^{\mathrm{ab}}\end{array}$ & $\begin{array}{l}110,47 \pm 6 \\
95 \text { a }\end{array}$ \\
\hline pA & $100 a$ & $\begin{array}{l}7,07 \pm 0,8 \\
3 \text { b }\end{array}$ & $\begin{array}{l}5,90 \pm 0,5 \\
7 \mathrm{~b}\end{array}$ & 23,69 & $\begin{array}{l}4,33 \pm 0, \\
19 \mathrm{~b}\end{array}$ & $\begin{array}{l}245.51 \pm 1 \\
5.93^{b}\end{array}$ & $\begin{array}{l}120,00 \pm 3 \\
64 \mathrm{~b}\end{array}$ \\
\hline pB & $\begin{array}{l}97,33 \pm 2 \\
, 31 \text { a }\end{array}$ & $\begin{array}{l}7,49 \pm 1,0 \\
8 b, c\end{array}$ & $\begin{array}{l}6,27 \pm 0,4 \\
2 \text { b,c }\end{array}$ & 31,45 & $\begin{array}{l}4,46 \pm 0 \\
13 b, c\end{array}$ & $\begin{array}{l}246.65 \pm 1 \\
4.70^{b}\end{array}$ & $\begin{array}{l}122,70 \pm 3 \\
19 b\end{array}$ \\
\hline $\mathrm{pC}$ & $\begin{array}{l}99 \pm \\
1,41 a\end{array}$ & $\begin{array}{l}7,83 \pm 1,5 \\
1 \mathrm{c}\end{array}$ & $\begin{array}{l}6,69 \pm 0,3 \\
0 c\end{array}$ & 40,25 & $\begin{array}{l}4,59 \pm 0, \\
09 \text { c }\end{array}$ & $\begin{array}{l}269.75 \pm 1 \\
0.50^{c}\end{array}$ & $\begin{array}{l}122,60 \pm 2 \\
, 26 \text { b }\end{array}$ \\
\hline
\end{tabular}

It is the first study revealed that feeding rEIGHcould significantly stimulate the growth of humpback grouper. Other study related with rEIGH was done by Handoyo (2012) to Indonesian eel fingerling by immersion, oral route and combination of immersion and oral; increasing growth subsequently as big as $37.4 \%, 65.7 \%$ and $102.9 \%$ higher than control. Same application methods were used by Subaidah (2013) for whiteshrimp, the growth of rEIGHtreatment group were $109.9 \%, 17.7 \%$ and $40.1 \%$ respectively higher than control. Other studies also demonstrated the efficiency of oral administrated $r G H s$ in promoting fish growth. Moriyama et al. (1993) reported that feeding recombinant salmon GH caused significant increase in body weight and length of rainbow trout. Oral delivery of recombinant fish GH induced a 1.6-fold increase in body weight of black seabream (Tsai et al., 1997).Promdonkoy et al. (2004) used rGH from giant catfish to goldfish by oral delivery found increasing body weight $84 \%$ higher than control. Despite the proteolytic enzymes in the gastrointestinal tract of fish could hydrolyze oral administrated $\mathrm{GH}$, the present result along 
with the cited reports above clearly demonstrated that dietary delivery of rGHin form of $r G H$ coated HP55is an effective approach to enhance fish growth.

As mentioned earlier, exogenous $\mathrm{GH}$ may enhances fish growth by stimulating appetite then increasing feed consume and improving feed conversion (Donaldson et al., 1979; Silverstein et al., 1999). This study showed that after consuming $\mathrm{rGH}$, growth rate, and appetite/feed consume and feed efficiency of humpback grouper significantly higher than control groups (Table 1). It isconsistent with study result ofMarkert et al. (1977) in salmonids, Wilson et al.(1988) and Silverstein et al. (2000) in channel catfish. Reversely Liv et al. (1999; 2008) found different result, feeding recombinant $\mathrm{GH}$ to flounder could promote fish growth and improve feed conversion, but did not affect feed intake. GH might stimulate food intake indirectly through metabolic changes such as increased utilization of nutrients that feedback on hypothalamic centers regulating energy balance (Silverstein et al., 1999). One of hypothalamic factors which may involve to regulate energy balance is ghrelin, where $\mathrm{GH}$ and ghrelin working together in a 2 ways mechanism (Wong et al., 2006). Further investigations are needed to verify relation between $\mathrm{GH}$ and ghrelin in promoting growth and feed consumption.

Table 2. Proximate composition of body muscle, liver and muscle glycogen, and plasma glucose of humpback grouper juvenile after 42 days trial.

\begin{tabular}{lllllll}
\hline Groups & Protein & Lipid & $\begin{array}{l}\text { Carbo- } \\
\text { hydrate }\end{array}$ & $\begin{array}{l}\text { Liver } \\
\text { Glycogen }\end{array}$ & $\begin{array}{l}\text { Muscle } \\
\text { Glycogen }\end{array}$ & $\begin{array}{l}\text { Plasma } \\
\text { Glucose }\end{array}$ \\
\hline C - & $16,89 \pm 0,34^{\mathrm{a}}$ & $5,85 \pm 0,16^{\mathrm{a}}$ & $2,69 \pm 0,29 \mathrm{a}$ & $4,11 \pm 0,51^{\mathrm{a}}$ & $4.99 \pm 0.58^{\mathrm{a}}$ & $55,78 \pm 13,10^{\mathrm{a}}$ \\
C + & $16,38 \pm 0,64^{\mathrm{a}}$ & $6,16 \pm 0,23^{\mathrm{a}}$ & $2,49 \pm 0,37^{\mathrm{a}}$ & $4,44 \pm 0,45^{\mathrm{a}}$ & $3.32 \pm 1.46^{\mathrm{a}}$ & $41,53 \pm 5,86^{\mathrm{a}}$ \\
PA & - & - & - & - & - & $58,86 \pm 12,79^{\mathrm{a}, \mathrm{b}}$ \\
PB & - & - & - & - & - & $59,65 \pm 15,48^{\mathrm{a}, \mathrm{b}}$ \\
PC & $19,32 \pm 0,53^{\mathrm{b}}$ & $6,22 \pm 0,10^{\mathrm{a}}$ & $2.81 \pm 0,10^{\mathrm{a}}$ & $5,56 \pm 0,31^{\mathrm{b}}$ & $3,77 \pm 0,56^{\mathrm{a}}$ & $81,95 \pm 12,85^{\mathrm{b}}$ \\
\hline
\end{tabular}

Different superscript letter in the same column indicated significant difference based on Duncan test $(\mathrm{P}<0.05)$.

Table 3. Hepatosomaticindex (HSI), protein retention (PR) and lipid retention (LR) of humpback grouper juvenile after 42 days trial.

\begin{tabular}{clll}
\hline Group & HSI & PR & LR \\
\hline C - & $2,99 \pm 0,76^{a}$ & $3,23 \pm 0,69^{a}$ & $-0,07 \pm 0,79 a$ \\
C + & $3,71 \pm 0,31^{a}$ & $2,18 \pm 1,30^{a}$ & $1,00 \pm 0,88^{a b}$ \\
PA & $4,46 \pm 1,29 a, b$ & - & - \\
PB & $4,89 \pm 1,21^{\mathrm{b}}$ & - & - \\
PC & $5,45 \pm 0,80^{\mathrm{b}}$ & $8,21 \pm 1,08^{\mathrm{b}}$ & $2,03 \pm 0,68^{\mathrm{b}}$ \\
\hline
\end{tabular}

Different superscript letter in the same column indicated significant difference based on Duncan test $(\mathrm{P}<0.05)$.

Protein content, liverglycogen and plasmaglucosefrom rGH treatment (represent by $\mathrm{pC}$ ) were significantly higher than both control groups. Eventhough lipid and carbohydrate content have tendency higher than control but statistically not different as well as muscle glycogen(Table 2). These findings were consistent that $\mathrm{GH}$ has direct metabolic effects including the stimulation of lipolysisand protein synthesis which were especially pronounced in muscle. GH also has diabetogenetic effect, that is induces peripheral resistance to insulin such that glucose cannot be used and blood glucose levels rise then increasing liver glycogen deposit (Bolander, 2004).Hepatosomatic index and protein retention were significantly higher 
than control whereas lipid retention significantly different than $C$ - but if compare with $C+$ not different (Table 3). A study in cohosalmon transgenic $\mathrm{GH}$ showed that $\mathrm{GH}$ able to increase HSI value 1.3 higher than control (Leggatet al., 2009). It has been known that the receptor of GH in fish mainly distributed in liver cells and liver is a main organ for GH to stimulate IGF-1 production (Moriyama and Kawauchi, 2001); therefore as a consequence of increasing IGF-1 production and other anabolic and katabolic metabolism GH treated organism needbigger size and capacity of liver.

Many studies have investigated the effect of $\mathrm{rGH}$ on fish body compositionspecifically on protein and lipid content. Silverstein et al. (2000) found that recombinant bGH injection induced protein and lipid content in USDA-103 and Norris strain of channel catfish. Whereas, Peterson et al. (2004) observed no effect of recombinant bGH injection on body composition in NWAC103 and Norris strain of channel catfish. According to Liu et al. (1999), crude protein and crude fat content of muscle in flounder were increased by feeding recombinant yeast containing salmon GH.However, Liu et al. (2008) reported that protein and lipid content in muscle of flounder were not changed by feeding GH transgenic SYN. Different result was reported on giant gourami after treated with $\mathrm{rGH}$, where lipid of treated fish was significantly lower than control groups. Investigation related to the lipid content showed that lipase enzyme activity in rGH treatment fish was higher than control (Irmawati, 2012). Protein and lipid content after feeding rGH are interesting topics for discussion;generally protein content is a desirable whereas lipid content is not desirable for commercially consumption fish cultured. Although fish size, age, diet and some experimental factors can affect to the body composition, the main cause for the different results obtained by different authors may more likely be the different responses to $\mathrm{rGH}$ treatment from different fish species and hormone dose used in experiments (Liv et al., 2008). Silverstein and Plisetskaya (2000) stated that the potential increasing body fatness after growth hormone treatment should be viewed with caution because increased body fat in juvenile fish may reduce feed intake for long time.

Histological examination showed that no apparent differences in the appearance of liver, kidney and spleen tissue of $C$ - and $p C$ (Figure 1 and 2). There were some histological abnormalities found in all organs studied from both experimental groups such as inclusionbody acidophilic,necrosis, hemorrhage, fatty degeneration, hydropicdegeneration, hyaline degeneration and melano macrophage center. Based on routine check in our laboratory, the appearance of inclusion body acidophilicindicating that experimental fishes from all treatment infected by iridovirus. Meanwhile, another cell abnormalities caused by several infectious and non-infectiousdiseases had been reported (Medlineplus Encyclopedia, 2013; Kurtovic et al., 2008; Agius and Roberts, 2003).Even though not clear what is the main cause of cell abnormalities in humpback grouper, since no specific histological damage which was attributable to $\mathrm{rGH}$ treatment group then it could be say that $\mathrm{rGH}$ consumption is safe for fish. This finding was consistent with several studies conducted before, such as by Liu et al. (2008) on flounder and Irmawati (2013) on giant gouramiwhich were found that rGH consumption 
didn't cause any specific histological damage for fish internal organs. In human clinical experience, $r G H$ consumption replacement therapy for long time indicating a lack of convincing evidence for an increased risk of cell abnormalities (Farris et al., 2007). However, quantitative histological study still needed to elucidate the safety of $r G H$ consumption in fish for longer duration.

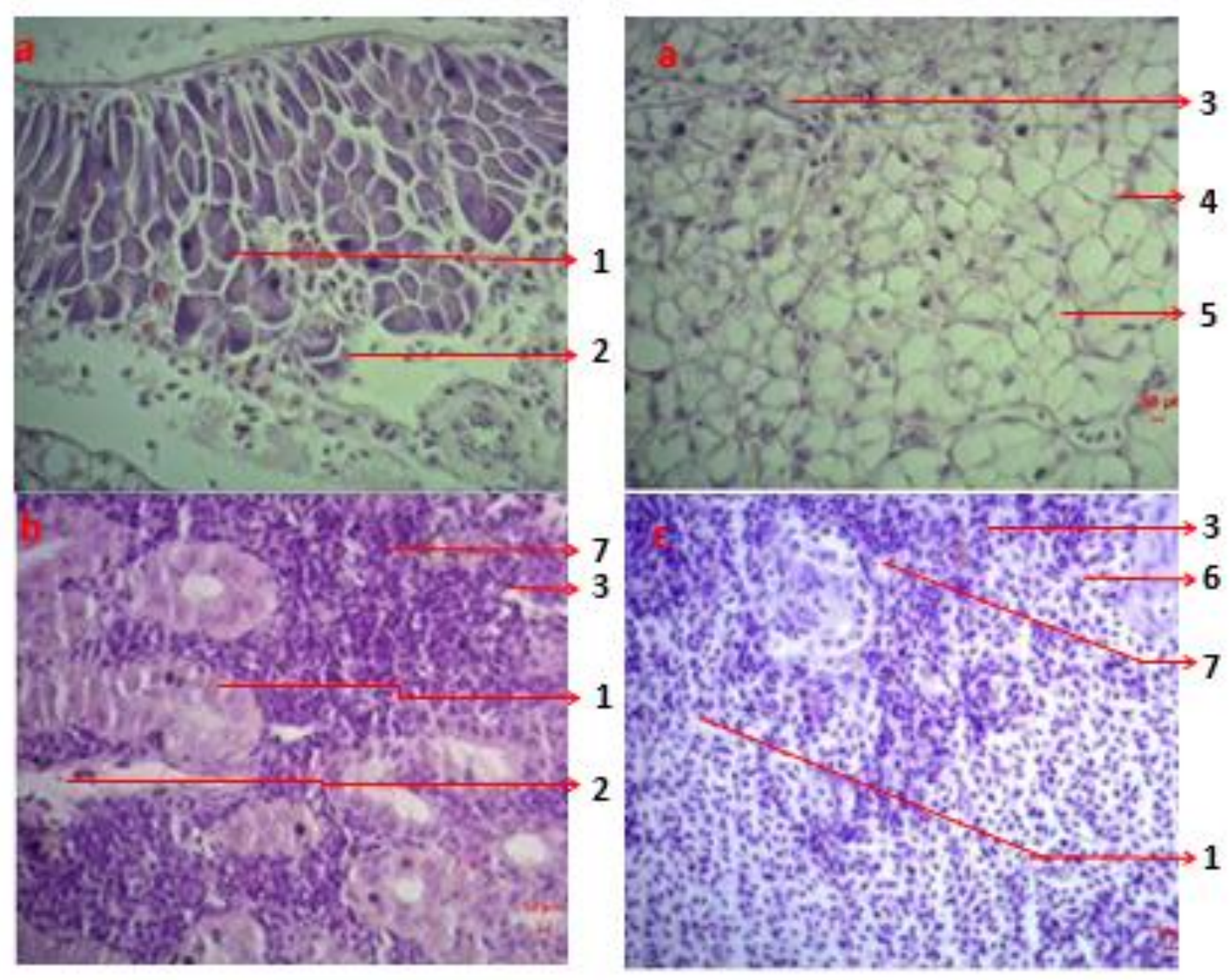

Figure 1. Histological appearance of liver (a), kidney (b), and spleen (c) of control

1. Inclusion body acidophilic; 2 . Hemorrhage; 3 . Necrosis; 4. Fatty degeneration cell; 5 . Hydropic degeneration cell; 6 . Hyaline degeneration cell; 7. Melanomacrophage center 

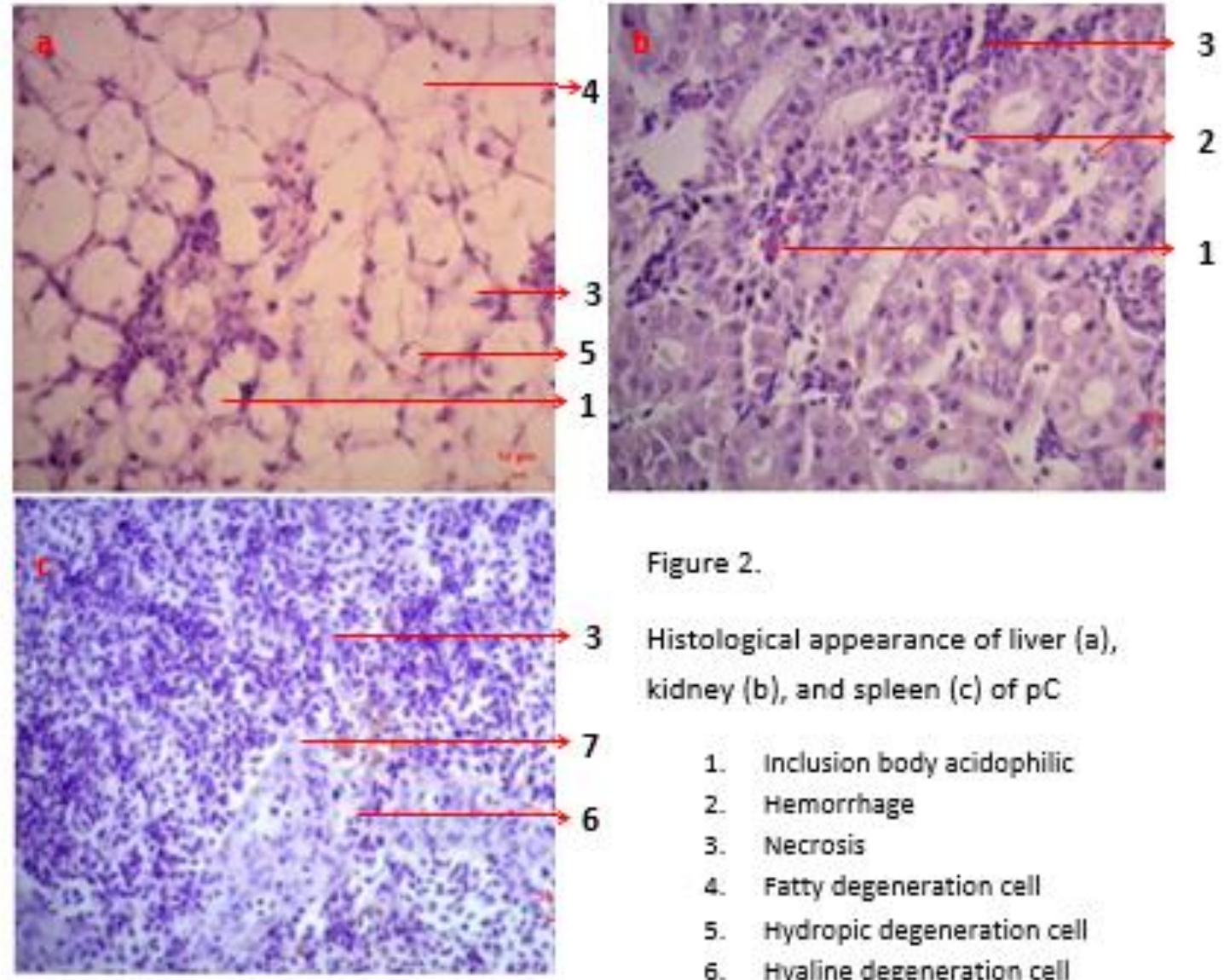

Figure 2 .

Histological appearance of liver (a),
kidney (b), and spleen (c) of $\mathrm{pC}$
1. Inclusion body acidophilic
2. Hemorrhage
3. Necrosis
4. Fatty degeneration cell
5. Hydropic degeneration cell
6. Hyaline degeneration cell

\section{CONCLUSION}

The study result clearly demonstrated that rGH from Epinepheluslanceolatusgene could enhanced the growth of humpback grouper and $\mathrm{rEIGH}$ administration by oral delivery to be an effective method and lookedto be an economically viable feed additive for fish culture at commercial scale. This study alsorevealed that $\mathrm{rGH}$ consumption has no negative effects onsurvival, muscle composition and histology of fish studied. However, as ourconclusions were based on a 6-week feeding trial,further investigations using other fish species, longtermfeeding experiment and quantitative histology examination should be undertaken to further confirm thegrowth-promoting effect and safety as feed additive of $\mathrm{rGH}$.

\section{Acknowledgements}

This study was supported by Human ResourcesAgency, Ministry of Marine and Fishery of the Republic of Indonesia.

\section{REFERENCES}

Acosta J, Morales R, Morales A, Alonso M, Estrada MP.2007. Pischiapastoris expressing recombinant tilapia growth hormone accelerates the growth of tilapia, Biotechnol. Lett. 29:1671-1676.

Agius C, Roberts RJ. 2003. Melano-macrophage centres and their role in fish pathology,J. Fish Diseases 26: 499-509. 
Alimuddin, Lesmana I, Sudrajat AO, Carman O, Faizal I. 2010. Production and bioactivity potential of three recombinant growth hormones of farmed fish.Indonesian Aquaculture Journal, 5:11-16.

Bin X, Kang-sen $M$, Ying-li X, H on g - zhii $M$, Zhen-hui L, Yong D, Shan L, Rao W, Pei-jun Z. 2001. Growth Promotion of RedSeabream, Pagrosomus mayor, by Oral Administrationof Recombinant Eel and Salmon Growth Hormone.Chinese Journal of Oceanology and limnologyVol.19 (2) P:141 - 146.

Birzniece V, Sata A, Ho KKY. 2009. Growth hormone receptor modulators. Rev. Endocr. Metab.Disord. 10: 145-156.

Bolander FF. 2004. Molecular Endocrinology, Ed ke-3. London: Elsevier Academic Press, 617pp.

Donaldson EM, Fagerlund UHM, Higgs DA, McBride JR. 1979. Hormonal enhancement of growth. In: Hoar WS, Randall DJ, Brett JR. (Eds.), Fish Physiology, vol. 8. Academic Press, New York, pp. 456- 598.

Farris GM, Miller GK, Wollenberg GK, Molon-Noblot S, Chan C, Prahalada S. 2007.Recombinant Rat and Mouse Growth Hormones: Risk Assessment of Carcinogenic Potential in 2-Year Bioassays in Rats and Mice. Toxicological Sciences 97(2): 548-561.

Funkenstein B, Dyman A, Lapidot Z, de Jesus-Ayson EG, Gertler A, Ayson FG. 2005. Expression and purification of a biologically active recombinant rabbitfish (Siganusguttatus) growth hormone. Aquaculture 250: 504-515.

Handoyo B. 2012. Response of Eel fingerling on Recombinant Giant Grouper Growth Hormone by immersion and oral administration (thesis).Bogor Agriculture University (in Indonesian with English Abstract).

Hattori N. 2009. Expression, regulation and biological actions of growth hormone (GH) and ghrelin in the immune system.Growth Hormone \& IGF Research, 19:1 87-197

Irmawati. 2013. Physiology, Biochemistry, and Molecular Responses of Giant Gourami Juvenile Treated by Recombinant Growth Hormone (disertation). Bogor Agriculture University (in Indonesian with English Abstract).

Kurtovic B, Teskeredzic E, Teskeredzic Z. 2008. Histological comparison of spleen and kidney tissue from farmed and wild European sea bass (DicentrarchuslabraxL.).ActaAdriat. 49 (2): $147-154$.

Leedom TA, Uchida K, Yada T, Richman III NH, Byatt JC, Collier RJ, Hirano T, Grau EG. 2002. Recombinant bovine growth hormone treatment of tilapia: growth response, metabolic clearance, receptor binding and immunoglobulin production. Aquaculture 207: 359-380.

Leggatt RA, Raven PA, Mommsen TP, Sakhrani D, Higgs D, Devlin RH. 2009. Growth hormone transgenesis influences carbohydrate, lipid and protein metabolism capacity for energy production in coho salmon (Oncorhynchuskisutch). Comparative Biochemistry and Physiology, Part B, 154:121-133.

Li Y, Bai J, Jian Q, Ye X, Lao H, Li X, Luo J, Liang X. 2003. Expression of common carp growth hormone in the yeast Pichiapastoris and growth stimulation of juvenile tilapia (Oreochromisniloticus).Aquaculture 216: 329-341.

Liu Z Zh, Xu YL, Xu DW, Zhang PJ. 1999. Effects of exogenous growth hormone on muscle composition of flounder (Paralichysolivaceus). Mar. Sci. 5: 51-53 (in Chinese, with English abstract).

Liu S, Zhang X, Zang X, Liu B, Arunakumara KKIU, Xu D, Zhang X. 2008. Growth, feed efficiency, body muscle composition, and histology of flounder (Paralichthysolivaceus) fed GH transgenic Synechocystis. Aquaculture 277: 78-82.

Markert JR, Higgs DA, Dye HM, MacQuarrie DW. 1977. Influence ofbovine growth hormone on growth rate, appetite, and food conversion ofyearling coho salmon (Oncorhynchuskisutch) fed two diets of differentcomposition. Can. J. Zool. 55: 74-83.

Moriyama S, Kawauchi H. 1990. Growth stimulation of juvenile salmonids by immersion in recombinant salmon growth hormone.Nippon SuishanGakkaishi56 (1):31-34.

Moriyama S, Yamamoto H, Sugimoto S, Abe T, Hirano T, Kawauchi H. 1993. Oral administration of recombinant salmon growth hormone to rainbow trout, Oncorhynchusmykiss. Aquaculture 112: 99-106.

Moriyama S, Felix GA, Hiroshi K. 2000. Growth regulation by insuline-like growth factor-1 in fish. Bioscience Biotechnology Biochemistry, 64:1553-1562.

Moriyama S, Kawauchi H. 2001. Growth regulation by growth hormone and insulin-like growth factor-I in teleosts.Otsuchi Mar. Sci. 26:23-27 
Muir WM, Howard RD. 1999. Possible ecological risks of transgenicorganism release when transgenes affect mating success: sexual selection andthe Trojan gene hypothesis. Proc. Natl. Acad. Sci. USA 96, 13853-13856.

Peterson BC, Small BC, Bosworth BG. 2004.Effects of bovine growth hormone (Posilac $($ ) on growth performance, body composition, and IGFBPs in two strains of channel catfish.Aquaculture 232:651-663.

Promdonkoy B, Warit S, Panyim S. 2004. Production of a biologically active growth hormone from giant catfish (Pangasianodongigas) in Escherichia coli. Biotechnology Letters 26: 649-653.

Reinecke $M$, Biörnsson BT, Dickhoff WW, McCormick SD, Navarro I, Power DM, Gutiérrez J. 2005. Growth hormone and insulin-like growth factors in Fish: Where we are and where to go. Gen.Comp.Endocrinol.1 42: 20-24

Sekine S. 1985. Cloning and expression of CDNA for salmon growth hormone in Escherichia coli.Proc. Nati. Acad. Sci. 82: 4306-4310.

Silverstein JT, Plisetskaya EM. 2000. The Effects of NPY and Insulin on Food Intake Regulation in Fish. Amer. Zool., 40:296-308

Silverstein JT, Wolters WR, Shimizu M, Dickhoff WW. 2000. Bovine growth hormone treatment of channel catfish: strain and temperature effects on growth, plasma IGF-I levels, feed intake efficiency and body composition. Aquaculture 190:77-88

Subaidah S. 2013. Growth Response and Immune of White Shrimp Litopenaeusvannamei on Administration of Recombinant Giant Grouper Growth Hormone (disertation). Bogor Agriculture University (in Indonesian with English Abstract)

Tsai HJ, Hsih MH, Kuo JC. 1997. Escherichia coli-produced fish growth hormone as a feed additive to enhance the growth of juvenile black seabream(Acanthopagrusschlegeli). J. Appl. Ichthyol. 13. 79-82.

Wilson RP, Poe WE, Nemetz TG, MacMillan JR. 1988.Effect of recombinant bovine growth hormone administration on growth and body composition of channel catfish.Aquaculture 7:229-238.

Wong AOL, Zhou H, Jiang Y, Ko KKW. 2006. Review: Feedback Regulation of Growth Hormone Synthesis and Secretion in Fish and the Emerging Concept of Intrapituitary Feedback Loop. Comp. Biochemp. Physiol., Part A 144:284 - 305. 